\title{
Hypoglycemic Effect of Insulin-like Growth Factor-1 in Mice Lacking Insulin Receptors
}

\author{
Giovanni Di Cola, Martha H. Cool, and Domenico Accili \\ Developmental Endocrinology Branch, National Institute of Child Health and Human Development, National Institutes of Health, \\ Bethesda, Maryland 20892
}

\begin{abstract}
We have investigated the metabolic actions of recombinant human IGF-1 in mice genetically deficient of insulin receptors $\left(I R^{-/-}\right)$. After intraperitoneal administration, IGF-1 caused a prompt and sustained decrease of plasma glucose levels in $I R^{-/-}$mice. Plasma free fatty acid concentrations were unaffected. Interestingly, the effects of IGF-1 were identical in normal mice $\left(I R^{+/+}\right)$and in $I R^{-/-}$mice. Despite decreased glucose levels, $I R^{-/-}$mice treated with IGF-1 died within $2-3 \mathrm{~d}$ of birth, like sham-treated $I R^{-/-}$controls. In skeletal muscle, IGF-1 treatment caused phosphorylation of IGF-1 receptors and increased the levels of the phosphatidylinositol-3-kinase p85 subunit detected in antiphosphotyrosine immunoprecipitates, consistent with the possibility that IGF-1 stimulates glucose uptake in a phosphatidylinositol-3-kinase-dependent manner. IGF-1 receptor phosphorylation and coimmunoprecipitation of phosphatidylinositol3-kinase by antiphosphotyrosine antibodies was also observed in liver, and was associated with a decrease in mRNA levels of the key gluconeogenetic enzyme phosphoenolpyruvate carboxykinase. Thus, the effect of IGF-1 on plasma glucose levels may be accounted for by increased peripheral glucose use and by inhibition of hepatic gluconeogenesis. These data indicate that IGF-1 can mimic insulin's effects on glucose metabolism by acting through its own receptor. The failure of IGF-1 to rescue the lethal phenotype due to lack of insulin receptors suggests that IGF-1 receptors cannot effectively mediate all the metabolic actions of insulin receptors. (J. Clin. Invest. 1997. 99:2538-2544.) Key words: diabetes mellitus $\bullet$ ketoacidosis $\bullet$ mutagenesis $\bullet$ genetics $\bullet$ insulin resistance
\end{abstract}

\section{Introduction}

Type I insulin-like growth factor (IGF-1) promotes growth and differentiation in a variety of tissues (1). These effects are largely mediated by the IGF-1 receptor, although IGF-1 can bind with low affinity to the insulin receptor (2). In addition to these effects, IGF-1 can mimic the metabolic actions of insulin to stimulate glucose and amino acid uptake, inhibit gluconeogenesis, and promote lipogenesis. Because of its metabolic effects, IGF-1 has been used in clinical trials of non-insulin-depen-

Address correspondence to Domenico Accili, M.D., Building 10 Room 10D18, Bethesda, MD 20892. Phone: 301-496-9595; FAX: 301402-0574; E-mail: accilid@cc1.nichd.nih.gov

Received for publication 26 November 1996 and accepted in revised form 24 February 1997.

The Journal of Clinical Investigation

Volume 99, Number 10, May 1997, 2538-2544 dent diabetes mellitus (NIDDM) ${ }^{1}$ patients and patients with genetic syndromes of insulin resistance as an insulin-sensitizing agent (3-9).

It is not clear whether the metabolic actions of IGF-1 are exerted through the insulin receptor or the IGF-1 receptor. Because the hypoglycemic effect of IGF-1 in normal human volunteers is $\sim 5 \%$ compared with that of insulin (4), and closely parallels the binding affinity of IGF-1 to insulin receptors, it has been proposed that the metabolic actions of IGF-1 are mediated by the insulin receptor, or by hybrid receptors composed of an insulin receptor monomer and an IGF-1 receptor monomer (10-13). On the other hand, the two receptors are highly homologous and are able to activate the same set of intracellular substrates, thus suggesting that the IGF-1 receptor has an intrinsic ability to activate pathways leading to metabolic responses (14-20).

Using gene targeting in embryonic stem cells, we have developed a mouse strain with a null allele of the insulin receptor gene. Absence of insulin receptors in mice gives rise to severe diabetic ketoacidosis immediately after birth, with death within 2-7 d (21, 22). Interestingly, unlike humans with similar mutations, $I R^{-l-}$ mice are not growth retarded, nor do they develop hypoglycemia, two well recognized complications of genetic syndromes of severe insulin resistance in man $(23,24)$. In the present study, we have addressed whether IGF-1 receptors can mediate the metabolic actions of IGF-1 in mice homozygous for a null allele of the insulin receptor. We report that IGF-1 is as effective in lowering plasma glucose levels in $I R^{-1-}$ as it is in $I R^{+/+}$mice. The hypoglycemic effect of IGF-1 is associated with an increase in the amount of phosphatidylinositol (PI)-3-kinase coimmunoprecipitated by antiphosphotyrosine antibodies in skeletal muscle and liver. This effect is consistent with the possibility that IGF-1 stimulates peripheral glucose uptake, although the latter could not be measured directly. Furthermore, IGF-1 treatment is also associated with a decrease in the levels of phosphoenolpyruvate-carboxykinase (PEPCK) mRNA in the liver, which may lead to inhibition of hepatic glucose production by decreasing gluconeogenesis. On the other hand, IGF-1 is not able to stimulate lipogenesis and rescue the lethal phenotype due to lack of insulin receptors. Thus, our study suggests that, while IGF-1 receptors can mediate some metabolic actions of IGF-1, they cannot fully compensate for the absence of insulin receptors.

\section{Methods}

IGF-1 administration. Intercrosses of mice heterozygous for the insulin receptor null allele were set up to generate homozygous null

1. Abbreviations used in this paper: NIDDM, non-insulin-dependent diabetes mellitus; PEPCK, phosphoenolpyruvate-carboxykinase; PI3-kinase, phosphatidylinositol-3-kinase. 
mice and control littermates. At birth, pups $(\sim 1 \mathrm{~g}$ body wt) were injected with $0.1 \mathrm{ml}$ saline solution containing $0.05 \mathrm{mg} / \mathrm{ml} \mathrm{recombinant}$ human IGF-1 (rhIGF-1; a kind gift of Genentech Inc., South San Francisco, CA), or with saline alone. Thereafter, mice were either killed within $30 \mathrm{~min}$ of injection or were returned to the cage, and the administration of IGF-1 was repeated after $12 \mathrm{~h}$. In some experiments, animals were not killed in order to investigate whether IGF-1 treatment would prolong their life span. However, $I R^{-1-}$ mice invariably died on day 2 or 3 . Animals were killed by decapitation, exsanguinated, and various organs were quickly removed and snap-frozen in liquid nitrogen for protein, RNA, and DNA isolation. Up to $20 \mu \mathrm{l}$ of blood were obtained from $I R^{+/+}$mice, and 5-10 $\mu$ from $I R^{-/-}$ mice. Plasma glucose levels were measured by a glucose oxidase assay, and insulin levels were measured by radio immunoassay. FFA levels were determined by an enzymatic assay (Wako Bioproducts, Richmond, VA).

PCR genotyping. To determine the genotype of newborn mice, DNA was prepared as described (21) and subjected to PCR amplification with two sets of primers, one to detect the wild-type allele, and one to detect the mutant allele. The primers to detect the wild-type allele are derived from the sequence of exon 4 of the mouse insulin receptor gene: upstream primer: 5'CTT GAT GTG CAC CCC ATG TCT 3'; downstream primer: 5' TCG GAT GTT GAT GAT CAG GCT $3{ }^{\prime}$. The primers to detect the mutant allele are derived from the sequence of the neomycin phosphotransferase gene; upstream primer: 5' GAT CGG CCA TTG AAC AAG ATG 3'; downstream primer: 5' CGC CAA GCT CTT CAG CAA TAT 3'. The size of the expected product is $120 \mathrm{bp}$ for the wild-type and $700 \mathrm{bp}$ for the mutant allele. Standard PCR conditions were employed: initial denaturation of $5 \mathrm{~min}$ at $95^{\circ} \mathrm{C}$, followed by 30 cycles with annealing at $55^{\circ} \mathrm{C}$, extension at $72^{\circ} \mathrm{C}$, and denaturation at $94^{\circ} \mathrm{C}$, all for $1 \min (21)$.

Immunoprecipitation and immunoblotting. Extracts of liver and hind limb muscle were prepared by solubilizing tissues in a buffer containing $1 \%$ Triton X-100, $50 \mathrm{mM}$ Hepes, $\mathrm{pH}$ 7.6, $150 \mathrm{mM} \mathrm{NaCl}, 1$ mM Na-pyrophosphate, $0.1 \mathrm{M} \mathrm{NaF}, 10 \mathrm{mM}$ Na-orthovanadate, $4 \mathrm{mM}$ EDTA, and protease inhibitors. After centrifugation to clarify the insoluble material, extracts were adjusted to a concentration of $0.5 \mathrm{mg} /$ $\mathrm{ml}$ and subjected to immunoprecipitation with the anti-IGF-1 receptor antibody AB-1 (Oncogene Science Inc., Manhasset, NY) or with the monoclonal antiphosphotyrosine antibody 4G10 (Upstate Biotechnology Inc., Lake Placid, NY). Immunocomplexes were collected by centrifugation after the addition of $40 \mu$ l of protein A-Sepharose slurry, washed three times in $0.1 \%$ Triton X-100 buffer, and analyzed by SDS-PAGE as previously described (21). Immunoblotting was performed as described with antiphosphotyrosine (Upstate Biotechnology Inc.), anti-PI-3-kinase p85 subunit (Upstate Biotechnology Inc.), and anti-IGF-1 receptor antibodies, followed by detection with a horseradish peroxidase-conjugated goat anti-rabbit or anti-mouse IgG. Densitometric scanning was performed to quantitate the intensity of the bands.

Purification of IGF-1 receptors. Confluent monolayers of SV40transformed hepatocytes (25) derived from either $I R^{+/+}$or $I R^{-/-}$ mice were solubilized in Triton X-100 buffer as described above, and the glycoprotein fraction was purified by batch affinity chromatography with wheat germ agglutinin-agarose (EY Laboratories Inc., San Mateo, CA). After elution with $0.3 \mathrm{M} n$-acetylglucosamine, the protein concentration was adjusted to $0.15 \mathrm{mg} / \mathrm{ml}$, and the extract was phosphorylated in the presence of $1 \mathrm{nM}$ rhIGF- 1 and $\gamma\left[{ }^{32} \mathrm{P}\right]$ ATP as described in previous publications (21). Phosphoproteins were analyzed by immunoprecipitation with anti-IGF-1 receptor antibody (Oncogene Science Inc.) followed by SDS-PAGE and autoradiography.

Northern blotting analysis. Total cellular RNA was isolated using a guanidinium isothiocyanate/acid phenol extraction procedure (21). Polyadenylated RNA was further purified by affinity chromatography over an oligo-d(T) column. Northern blotting was performed according to standard techniques using ${ }^{32} \mathrm{P}$-labeled probes encoding the rat PEPCK (26), the mouse IGF-1 receptor (27), or the rat IGFBP-1 (28).

\section{Results}

To determine the effects of IGF-1 in mice lacking insulin receptors, newborn mice were treated with rhIGF-1 at a dose of $5 \mathrm{mg} / \mathrm{kg}$ or with saline by intraperitoneal injection. The high dose of IGF-1 was chosen to saturate IGF-1 binding to circulating IGF binding proteins. Insulin is known to inhibit expression of IGFBP-1 $(29,30)$. Therefore, since insulin action is inhibited in $I R^{-/-}$mice by the absence of insulin receptors, we expected IGFBP-1 levels to be elevated in $I R^{-/-}$mice. To test this hypothesis, Northern blot analysis was performed on RNA extracted from livers of newborn $I R^{-/-}$and $I R^{+/+}$mice (Fig. 1). When the blots were probed with a ${ }^{32} \mathrm{P}$-labeled rat IGFBP-1 cDNA, a 2.5-fold increase in IGFBP-1 levels was detected in newborn $I R^{-/-}$mice. Thus, the lack of insulin action in $I R^{-/-}$mice causes an increase in IGFBP-1 levels.

A single dose of rhIGF-1 caused a $50 \%$ decrease of plasma glucose levels in $I R^{+/+}$mice, a $30 \%$ decrease in mice heterozygous for the insulin receptor mutation $\left(I R^{+/-}\right)$, and a $60 \%$ decrease in $I R^{-/-}$mice (Fig. 2). The decrease was apparent within 1-2 min of the IGF-1 injection and persisted for at least $2 \mathrm{~h}$ (data not shown). Similar results were obtained with daily IGF-1 injections for $2 \mathrm{~d}$ (data not shown). At least 15 animals of each genotype were assayed for each treatment group. Thus, IGF-1 has both an acute and a chronic effect to decrease plasma glucose levels in $I R^{-/-}$mice.

To investigate whether the hypoglycemic effect of IGF-1 would rescue the lethal phenotype of $I R^{-/-}$mice, animals were injected within a few hours $(<6)$ of birth, before the onset of overt ketoacidosis, and treatment was repeated every $12 \mathrm{~h}$ thereafter. Invariably, $I R^{-/-}$mice died of ketoacidosis between days 2 and 3 of treatment, suggesting that administration of IGF-1 cannot rescue the metabolic abnormalities caused by lack of insulin receptors.

We also investigated the effect of IGF-1 treatment on

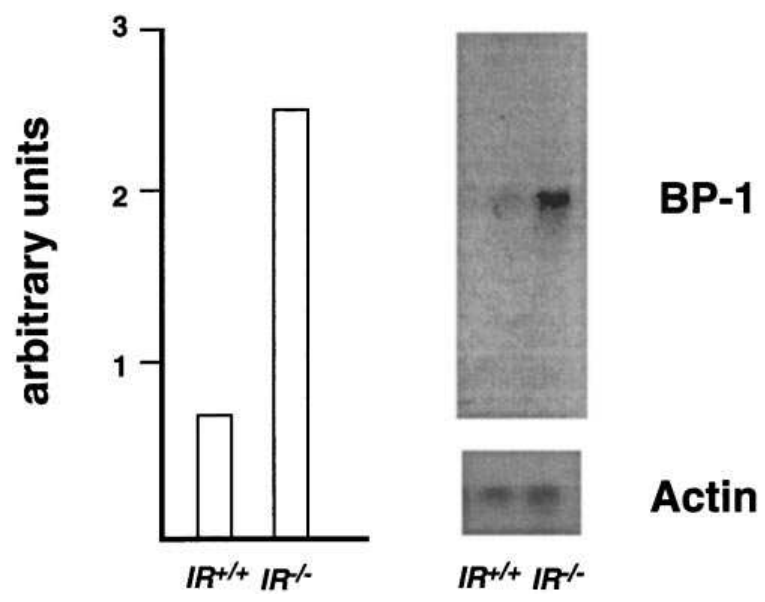

Figure 1. Northern blotting analysis of IGFBP-1 levels in livers of newborn $I R^{+/+}$and $I R^{-/-}$mice. Total RNA was isolated from livers of $I R^{+/+}$and $I R^{-/-}$mice, size-fractionated on a denaturing agarose/ formaldehyde gel, and transferred to nitrocellulose filters. Filters were hybridized with a ${ }^{32} \mathrm{P}$-labeled probe encoding the rat IGFBP-1 cDNA. As a control, blots were stripped and rehybridized with an actin cDNA probe. A quantitative representation of the data (corrected for actin levels) is shown in the panel on the left of the autoradiogram. 


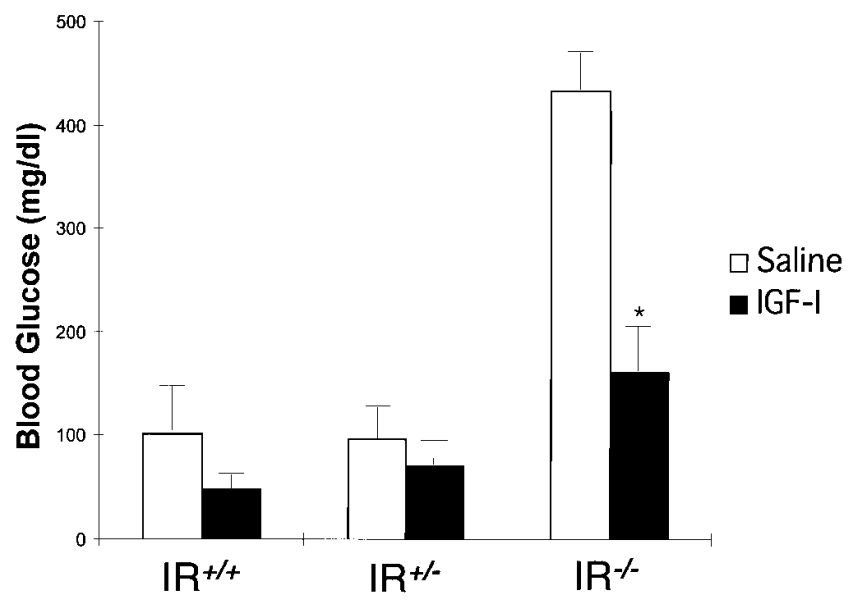

Figure 2. Plasma glucose levels after a single intraperitoneal injection of rhIGF-1. Newborn mice were injected with rhIGF-1 at a dose of $5 \mathrm{mg} / \mathrm{kg}$, killed by decapitation, and plasma glucose levels were measured. Empty bars represent saline-injected mice, whereas solid bars represent IGF-1-injected mice. Plasma glucose levels are indicated on the vertical axis in milligrams per deciliter.

plasma FFA levels. Unlike glucose levels, FFA levels did not change appreciably in IGF-1-treated mice (data not shown).

Hyperglycemia in $I R^{-1-}$ mice results from the compounded lack of insulin effect to stimulate glucose uptake and suppress hepatic glucose production. To determine the primary site(s) of action of IGF-1 in $I R^{-1-}$ mice, we measured autophosphorylation of IGF-1 receptors in hind limb muscle and liver extracts, and the ability of autophosphorylated IGF-1 receptors to catalyze the association of the regulatory (p85) subunit of PI-3-kinase with IRS molecules. A direct assessment of pe-

\section{Muscle Liver}
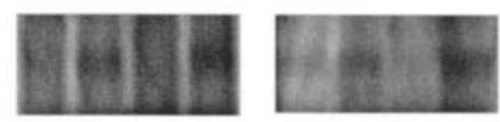

Ip: $\alpha \mathrm{PY}$

IB: $\alpha$ IGF-I

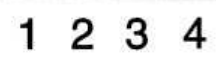

$\begin{array}{llll}5 & 6 & 7 & 8\end{array}$
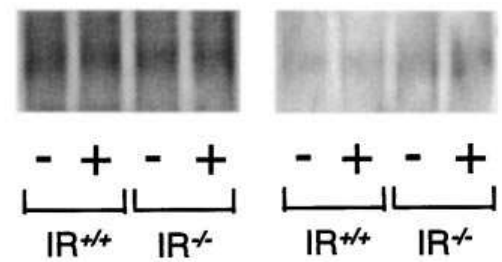

Ip: $\alpha$ IGF-I

IB: $\alpha$ IGF-I

IGF-I

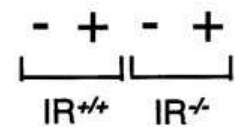

IR

Figure 3. Immunoblot analysis of IGF-1-induced phosphorylation of the IGF-1 receptor in skeletal muscle and liver. Newborn mice were treated with IGF-1 as described in Methods, and their hind limb skeletal muscles (lanes 1-4) and livers (lanes 5-8) were quickly isolated and frozen. Proteins were solubilized in Triton X-100. Immunoprecipitation was performed with antiphosphotyrosine antibody (top), or anti-IGF-1 receptor antibodies (bottom), followed by immunoblotting with an antibody against the IGF-1 receptor. Lanes 1 and 5 , sham-injected $I R^{+/+}$mice; lanes 2 and 6 , IGF-1-injected $I R^{+/+}$mice; lanes 3 and 7 , sham-injected $I R^{-/-}$mice; lanes 4 and 8 , IGF-1injected $I R^{-/-}$mice. Organs from three animals were pooled for each determination. ripheral glucose uptake was not possible due to the small size of the animals $(\sim 1 \mathrm{~g}$ body wt).

Phosphorylation of IGF-1 receptors was determined in muscle and liver extracts of IGF-1-treated and control mice (Fig. 3). After IGF-1 treatment, IGF-1 receptors were isolated from detergent extracts by immunoprecipitation with antiphosphotyrosine antibody. The immunoprecipitates were analyzed by immunoblotting with anti-IGF-1 receptor antibody (Fig. 3, top). IGF-1 increased to the same extent tyrosine phosphorylation of the IGF-1 receptor $\beta$-subunit in $I R^{+/+}$mice (Fig. 3, lanes 1, 2, 5, and 6, top) and in $I R^{-1-}$ mice (Fig. 3, lanes $3,4,7$, and 8 , top). Immunoprecipitation and blotting with anti-IGF-1 receptor antibody showed that an equal amount of receptor was loaded in all lanes (Fig. 3, lanes 1-8, bottom).

An important step in insulin- and IGF-1-stimulated glucose uptake is the activation of PI-3-kinase through its interaction with phosphorylated YXXM motifs in IRS-1 and -2 (20, 31-34). Since the majority of PI-3-kinase found in antiphosphotyrosine immunoprecipitates is bound to IRS-1 $(32,35,36)$, we set out to determine whether IGF-1 increased the amount of the p85 subunit of PI-3-kinase detected in antiphosphotyrosine immunoprecipitates from muscles and livers of control and treated $I R^{+/+}$and $I R^{-/-}$mice. Phosphotyrosine-containing proteins were isolated by immunoprecipitation with antiphosphotyrosine antibodies. After transferring the immunoprecipitates to a nitrocellulose filter, the amount of PI-3-kinase was estimated by immunoblotting with an antibody against $\mathrm{p} 85$. A direct assessment of PI-3-kinase activity was not possible, due to the small amount of material recovered from each mouse. In skeletal muscle of $I R^{+/+}$mice, IGF-1 treatment caused a 2.4fold increase in the amount of PI-3-kinase detected by immunoblotting of antiphosphotyrosine immunoprecipitates with an anti-p85 antibody. In $I R^{-1-}$ mice, a threefold increase was detected (Fig. 4). In liver, IGF-1 treatment was associated with a 1.4-fold increase of coimmunoprecipitated PI-3-kinase in $I R^{+/+}$ mice, and with a twofold increase in $I R^{-1-}$ mice (Fig. 4). All experiments were performed on pooled animal organs multiple times with virtually identical results.

Activation of PI-3-kinase in liver is required for insulin's
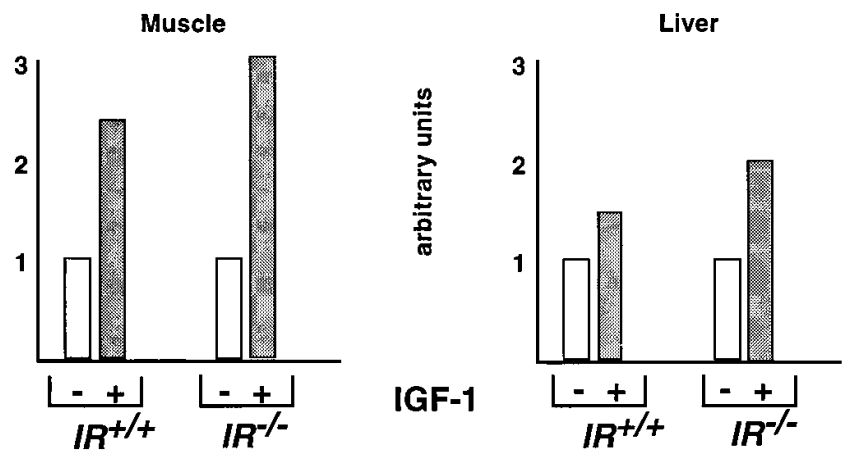

Figure 4. Coimmunoprecipitation of PI-3-kinase p85 subunit with antiphosphotyrosine antibodies. Hind limb muscle and liver extracts of $I R^{+/+}$and $I R^{-/-}$mice were solubilized with Triton X-100 and subjected to immunoprecipitation with an antiphosphotyrosine antibody. The immunopellets were analyzed by SDS-PAGE followed by immunoblotting with an anti-p85 antibody. The bands corresponding to the p85 subunit of PI-3-kinase were quantitated by scanning densitometry. Three separate experiments were performed and organs from three animals were pooled for each experiment. 


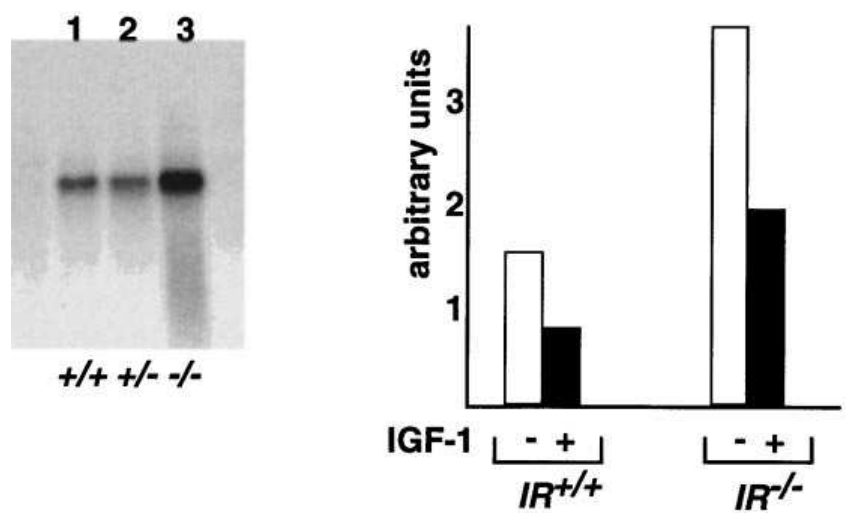

Figure 5. Northern blotting analysis of PEPCK gene expression in mouse liver. Total RNA was isolated from livers of control and IGF-1-treated mice, size-fractionated on a denaturing agarose-formaldehyde gel and transferred to nitrocellulose. After hybridization of the filter to a ${ }^{32} \mathrm{P}$-labeled rat PEPCK probe, the intensity of the bands was quantitated using scanning densitometry. The filters were stripped and reprobed with an actin control to normalize the intensity of the signal to the amount of RNA loaded onto each lane. The autoradiogram on the left side shows the basal levels of PEPCK expression in sham-treated animals (lane $1, I R^{+/+}$; lane $2, I R^{+/-}$; lane $3, I R^{-/-}$). The bar graph on the right side shows a quantitation of the effect of IGF-1 treatment in $I R^{+/+}$and $I R^{-/-}$mice. Livers from three animals were pooled for each determination. Data are presented as a percentage of the basal values in sham-treated animals.

effect to suppress transcription of the gluconeogenetic enzyme PEPCK (37). To determine the contribution of reduced hepatic gluconeogenesis to the hypoglycemic effect of IGF-1 in $I R^{-1-}$ mice, we measured PEPCK mRNA levels in livers of control and IGF-1-treated $I R^{+/+}$and $I R^{-/-}$mice by Northern blotting (Fig. 5). RNA was extracted from livers and PEPCK mRNA levels were determined by hybridization with a ${ }^{32} \mathrm{P}-$ labeled rat PEPCK probe. In untreated $I R^{-1-}$ mice, PEPCK mRNA levels are increased threefold compared with $I R^{+/+}$ and $I R^{+/-}$mice (Fig. 5, left). After IGF-1 treatment, PEPCK mRNA levels decreased by $30 \%$ in $I R^{+/+}$mice and by $50 \%$ in $I R^{-1-}$ mice, suggesting that the effect of IGF-1 on plasma glucose levels is at least in part mediated by decreased gluconeogenesis (Fig. 5, right).

IGF-1 receptors are expressed at very low levels in liver under physiologic conditions $(37,38)$. We wanted to determine whether the effect of IGF-1 on PEPCK gene expression could be explained by increased levels of IGF-1 receptors. However, Northern blotting analysis on polyA ${ }^{+}$RNA derived from $I R^{+/+}$ and $I R^{-1-}$ mice indicated that the levels of expression of IGF-1 receptors are similar in the two groups (Fig. $6 \mathrm{~A}$, lanes 4 and 6 ) and that IGF-1 receptor mRNA in liver is about threefold less abundant than in skeletal muscle (Fig. $6 A$, lanes $1-3$ vs. 4-6; please note that $2 \mu \mathrm{g}$ of polyA ${ }^{+}$RNA were loaded in lanes $1-3$, and $3 \mu \mathrm{g}$ in lanes 4-6). Likewise, immunoprecipitation of tyrosine-phosphorylated IGF-1 receptors from $I R^{+/+}$and $I R^{-/-}$ mice did not reveal any quantitative difference in the phosphorylation of hepatic IGF-1 receptors (Fig. 3, lanes 5-8). It is possible that IGF-1 receptors identified in whole liver preparations are derived from cell types other than the hepatocyte. To address the question of whether IGF-1 receptors are expressed by murine hepatocytes, we employed hepatocyte cell lines de- rived from $I R^{+/+}$and $I R^{-/-}$mice liver (K. Rother, Y. Imai, and D. Accili, manuscript in preparation). IGF-1 receptors were partially purified from these cells using lectin chromatography, and were phosphorylated in vitro using rhIGF-1 ( $1 \mathrm{nM})$ and $\gamma\left[{ }^{32} \mathrm{P}\right]$ ATP. Consistent with the results obtained in whole liver extracts, $I R^{+/+}$and $I R^{-/-}$hepatocytes express comparable amounts of IGF-1 receptors (Fig. 6 B, lanes 7-10). Thus, the effect of IGF-1 on PEPCK gene expression is not explained by increased levels of IGF-1 receptors in liver, and probably reflects a physiologic response to IGF-1.

\section{Discussion}

Type I insulin-like growth factor can mimic some of insulin's effects on fuel metabolism (3). However, it is not clear whether the metabolic effects of IGF- 1 are mediated by the IGF-1 receptor or by the insulin receptor. In the present study, we have addressed this question using a model of insulin receptor-deficient mice generated by targeted inactivation of the insulin receptor gene. Because lack of insulin receptors is rapidly lethal after birth, we could only perform these experiments in newborn mice. There are two main limitations to our study: first, metabolic regulation in newborn rodents is different from adult rodents and humans. Second, due to the small size of the animals, a complete analysis of IGF-1 effects at the target cell level was not possible.

The main result of this study is that IGF-1 can lower plasma glucose levels in $I R^{-/-}$mice, but fails to rescue the lethal phenotype due to the insulin receptor gene mutation. The persistent hyperglycemic state of insulin receptor-deficient mice indicates that the metabolic effects of IGF-1 through the IGF-1 receptor are not sufficient to replace completely the effects of insulin. An alternative explanation is that the metabolic derangement caused by the lack of insulin receptors impairs the response to IGF-1. However, treatment with IGF-1 was begun before the onset of overt ketoacidosis and was unable to prevent it.

Phosphorylation of IGF-1 receptors was readily detected in skeletal muscle and liver of $I R^{-/-}$and $I R^{+/+}$mice, and was paralleled by an increased amount of PI-3-kinase in antiphosphotyrosine immunoprecipitates, suggesting that IGF-1 may stimulate glucose uptake in skeletal muscle. This possibility is also consistent with the rapid onset of the hypoglycemic effect of IGF-1, which cannot be accounted for by decreased hepatic glucose output, the onset of which is considerably slower (39). The small size of the animals prevented us from measuring directly glucose uptake and PI-3-kinase activity in different subcellular fractions. Since activation of PI-3-kinase in response to IGF-1 has also been linked to the mitogenic response to IGF-1 (2), a more conclusive interpretation of these data awaits further experiments in cultured cells derived from $I R^{-1-}$ mice.

The hypoglycemic effect of IGF-1 is also associated with decreased gluconeogenesis, which is inappropriately elevated in $I R^{-1-}$ mice. Suppression of PEPCK gene expression in $I R^{-/-}$ mice was as marked as in $I R^{+/+}$mice. It remains to be determined whether this effect is due to a direct activation of the scarce hepatic IGF-1 receptors $(37,38)$, or to an indirect effect mediated by inhibition of glucagon secretion $(40,41)$. Interestingly, this effect is consistent with studies of humans with NIDDM, in whom IGF-1 treatment is quite effective in improving fasting glucose levels, an indicator of hepatic gluconeogenesis $(7,41,42)$. 


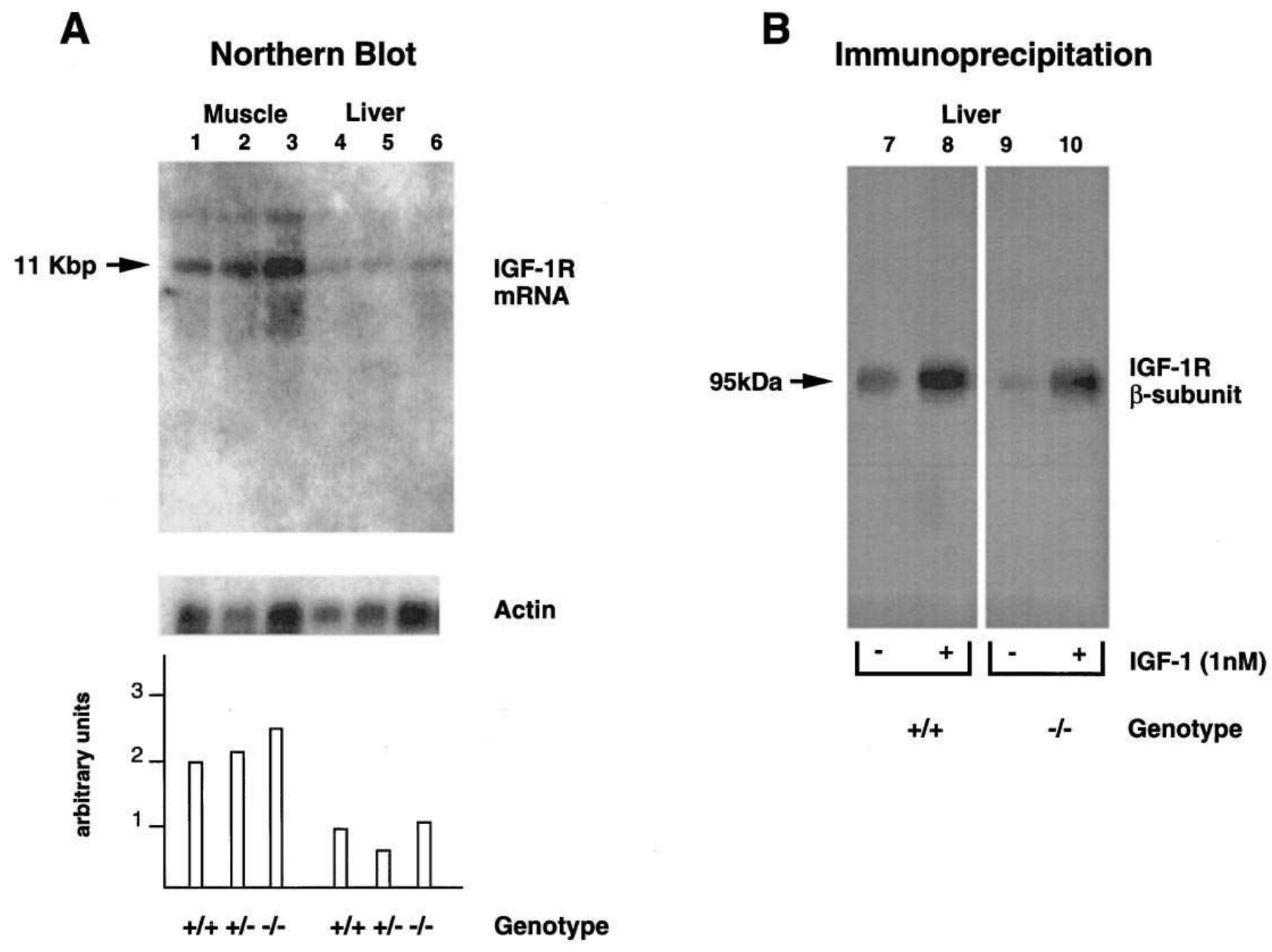

Figure 6. Analysis of IGF-1 receptor expression in liver. (A) PolyA ${ }^{+}$RNA was isolated from skeletal muscles (lanes 1-3) and livers (lanes 4-6) by affinity chromatography over oligo-(d)T cellulose and analyzed by Northern blotting. $2 \mu \mathrm{g}$ of polyadenylated RNA were loaded in lanes $1-3$, and $3 \mu \mathrm{g}$ in lanes 4-6. Hybridization to a mouse IGF-1 receptor cDNA probe and quantitation were performed as described in Methods. $(B)$ In vitro phosphorylation of lectin-purified IGF-1 receptors isolated from SV40-transformed hepatocytes from $I R^{+/+}$and $I R^{-/-}$mice. Glycoproteins were incubated in the absence or presence of $1 \mathrm{nM}$ rhIGF-1 for $1 \mathrm{~h}$ at room temperature, phosphorylated with $\gamma\left[{ }^{32} \mathrm{P}\right] \mathrm{ATP}$, and immunoprecipitated with an anti-IGF-1 receptor antibody (see Methods). Autoradiography was employed to detect the phosphorylated $\beta$-subunit of the IGF-1 receptor.

IGF-1 treatment failed to lower FFA levels in $I R^{+/+}$and $I R^{-1-}$ mice. The failure of IGF-1 to promote lipogenesis and thus decrease FFA levels is consistent with some data in normal human subjects after chronic IGF-1 administration (43). However, in most human and animal studies, IGF-1 has been shown to decrease FFAs and triglyceride levels (7, 41, 44). It should be emphasized that the effect of IGF-1 in our experimental model may be influenced by the fact that newborn mice are in a physiologic state of ketosis due to their high fat diet ( $\sim 70 \%$ of all caloric intake) (45-47). Elevated levels of circulating triglycerides may explain the persistent ketotic state of the $I R^{-1-}$ mice after IGF-1 treatment.

Several studies have analyzed the effects of IGF-1 in patients with varying degrees of insulin resistance and NIDDM. IGF-1 improves metabolic control in patients with NIDDM by improving insulin sensitivity, reducing glucose levels, and suppressing FFA release from adipocytes. Significant side effects have been reported in some patients $(7,48)$. Interestingly, data in insulin-resistant humans and rodents show that IGF-1 is more potent in suppressing hepatic glucose production $(7,41$, $42)$ than in stimulating glucose uptake in skeletal muscle $(49,50)$.

The effects of IGF-1 in patients with genetic syndromes of insulin resistance are less clear. In patients whose insulin resistance is due to mutations of the insulin receptor gene, it appears that higher doses of IGF-1 are required to improve metabolic control $(8,51-56)$. Thus, it is possible that in these patients the effects of IGF-1 are due to activation of residual insulin receptors or hybrid insulin/IGF-1 receptors. Indeed, most patients with extreme insulin resistance retain some degree of insulin receptor function. Interestingly, IGF-1 failed to improve the metabolic control of a patient homozygous for a null allele of the insulin receptor gene (51), but high doses of IGF-1 (1 mg/kg) improved metabolic control in a patient homozygous for a mutation in the insulin receptor's kinase domain (57). In summary, it is not clear whether in humans IGF-1 can act as a hypoglycemic agent in the absence of insulin receptors. Thus, there may be significant differences between humans and rodents with respect to the ability of IGF-1 recep- 
tors to mediate fuel metabolism. Our studies indicate that in newborn rodents IGF-1 can lower plasma glucose levels through its own receptor in the absence of insulin receptors. The derivation of permanent cultured cells from $I R^{-1-}$ mice will enable us to address whether IGF-1 receptors mediate this effect directly or through inhibition of counter-regulatory hormones.

\section{Acknowledgments}

We thank Dr. Ross Clark (Genentech Inc.) for advice on IGF-1 administration. We are indebted to Genentech Inc. for the generous gift of rhIGF-1, and to Dr. Guck T. Ooi (National Institutes of Health) for the gift of the rat IGFBP-1 probe. Finally, we thank Dr. Derek LeRoith (National Institutes of Health) for his critical reading of the manuscript.

These studies were partially supported through a research grant of the American Diabetes Association to D. Accili.

\section{References}

1. Baker, J., J.P. Liu, E.J. Robertson, and A. Efstratiadis. 1993. Role of insulin-like growth factors in embryonic and postnatal growth. Cell. 75:73-82.

2. LeRoith, D., H. Werner, D. Beitner-Johnson, and C. Roberts. 1995. Molecular and cellular aspects of the insulin-like growth factor I receptor. Endocr. Rev. 16:143-163.

3. Froesch, E.R., T. Bianda, and M.A. Hussain. 1996. Insulin-like growth factor-I in the therapy of non-insulin-dependent diabetes mellitus and insulin resistance. Diabetes Metab. 22:261-267.

4. Guler, H.P., J. Zapf, and E.R. Froesch. 1987. Short-term metabolic effects of recombinant human insulin-like growth factor I in healthy adults. $N$. Engl. J. Med. 317:137-140.

5. Zenobi, P.D., Y. Glatz, A. Keller, S. Graf, G.S. Jaeggi, W.F. Riesen, E.J. Schoenle, and E.R. Froesch. 1994. Beneficial metabolic effects of insulin-like growth factor I in patients with severe insulin-resistant diabetes type A. Eur. J. Endocrinol. 131:251-257.

6. Moses, A.C., L.A. Morrow, M. O'Brien, D.E. Moller, and J.S. Flier. 1995. Insulin-like growth factor I (rhIGF-I) as a therapeutic agent for hyperinsulinemic insulin-resistant diabetes mellitus. Diabetes Res. Clin. Pract. 28(Suppl. 1): 185-194.

7. Moses, A.C., S.C. Young, L.A. Morrow, M. O'Brien, and D.R. Clemmons. 1996. Recombinant human insulin-like growth factor I increases insulin sensitivity and improves glycemic control in type II diabetes. Diabetes. 45: 91-100.

8. Morrow, L.A., M.B. O'Brien, D.E. Moller, J.S. Flier, and A.C. Moses. 1994. Recombinant human insulin-like growth factor-I therapy improves glycemic control and insulin action in the type A syndrome of severe insulin resistance. J. Clin. Endocrinol. Metab. 79:205-210.

9. Bondy, C.A., L.E. Underwood, D.R. Clemmons, H.P. Guler, M.A. Bach, and M. Skarulis. 1994. Clinical uses of insulin-like growth factor I. Ann. Intern. Med. 120:593-601.

10. Soos, M.A., C.E. Field, and K. Siddle. 1993. Purified hybrid insulin/insulin-like growth factor-I receptors bind insulin-like growth factor-I, but not insulin, with high affinity. Biochem. J. 290:419-426.

11. Pessin, J.E. 1993. Molecular properties of insulin/IGF-1 hybrid receptors. 4th International Symposium on Insulin, IGFs and their Receptors. Adv. Exp. Med. Biol. 343:133-144.

12. Frattali, A.L., J.L. Treadway, and J.E. Pessin. 1992. Insulin/IGF-1 hybrid receptors: implications for the dominant-negative phenotype in syndromes of insulin resistance. J. Cell. Biochem. 48:43-50.

13. Treadway, J.L., B.D. Morrison, M.A. Soos, K. Siddle, J. Olefsky, A. Ullrich, D.A. McClain, and J.E. Pessin. 1991. Transdominant inhibition of tyrosine kinase activity in mutant insulin/insulin-like growth factor I hybrid receptors. Proc. Natl. Acad. Sci. USA. 88:214-218.

14. Cheatham, B., and C.R. Kahn. 1995. Insulin action and the insulin signaling network. Endocr. Rev. 16:117-142.

15. Lund, S., A. Flyvbjerg, G.D. Holman, F.S. Larsen, O. Pedersen, and O. Schmitz. 1994. Comparative effects of IGF-I and insulin on the glucose transporter system in rat muscle. Am. J. Physiol. 267:E461-E466.

16. Yu, K.T., and M.P. Czech. 1984. The type I insulin-like growth factor receptor mediates the rapid effects of multiplication-stimulating activity on membrane transport systems in rat soleus muscle. J. Biol. Chem. 259:3090-3095.

17. Poggi, C., M. Le, Y. Brustel, J. Zapf, E.R. Froesch, and P. Freychet. 1979. Effects and binding of insulin-like growth factor I in the isolated soleus muscle of lean and obese mice: comparison with insulin. Endocrinology. 105: $723-730$.
18. Bilan, P.J., T. Ramlal, and A. Klip. 1991. IGF-I mediated recruitment of glucose transporters from intracellular membranes to plasma membranes in L6 muscle cells. Adv. Exp. Med. Biol. 293:273-288.

19. Myers, M.J., T.C. Grammer, L.M. Wang, X.J. Sun, J.H. Pierce, J. Blenis, and M.F. White. 1994. Insulin receptor substrate-1 mediates phosphatidylinositol $3^{\prime}$-kinase and p70S6k signaling during insulin, insulin-like growth factor-1, and interleukin-4 stimulation. J. Biol. Chem. 269:28783-28789.

20. Myers, M.J., X.J. Sun, B. Cheatham, B.R. Jachna, E.M. Glasheen, J.M. Backer, and M.F. White. 1993. IRS-1 is a common element in insulin and insulin-like growth factor-I signaling to the phosphatidylinositol 3'-kinase. Endocrinology. 132:1421-1430.

21. Accili, D., J. Drago, E.J. Lee, M.D. Johnson, M.H. Cool, P. Salvatore, L.D. Asico, P.A. Jose, S.I. Taylor, and H. Westphal. 1996. Early neonatal death in mice homozygous for a null allele of the insulin receptor gene. Nat. Genet. 12: 106-109.

22. Joshi, R.L., B. Lamothe, N. Cordonnier, K. Mesbah, E. Monthioux, J. Jami, and D. Bucchini. 1996. Targeted disruption of the insulin receptor gene in the mouse results in neonatal lethality. EMBO (Eur. Mol. Biol. Organ.) J. 15: $1542-1547$.

23. Taylor, S.I. 1992. Lilly Lecture: molecular mechanisms of insulin resistance. Lessons from patients with mutations in the insulin-receptor gene. Diabetes. 41:1473-1490.

24. Accili, D. 1995. Molecular defects of the insulin receptor gene. Diabetes. Metab. Rev. 11:47-62.

25. Chou, J.Y. 1985. Establishment of rat fetal liver lines and characterization of their metabolic and hormonal properties: use of temperature-sensitive SV40 virus. Methods Emzymol. 109:385-396.

26. Beale, E.G., N.B. Chrapkiewicz, H.A. Scoble, R.J. Metz, D.P. Quick, R.L. Noble, J.E. Donelson, K. Biemann, and D.K. Granner. 1985. Rat hepatic cytosolic phosphoenolpyruvate carboxykinase (GTP). Structures of the protein, messenger RNA, and gene. J. Biol. Chem. 260:10748-10760.

27. Wada, J., Z.Z. Liu, K. Alvares, A. Kumar, E. Wallner, H. Makino, and Y.S. Kanwar. 1993. Cloning of cDNA for the alpha subunit of mouse insulinlike growth factor I receptor and the role of the receptor in metanephric development. Proc. Natl. Acad. Sci. USA. 90:10360-10364.

28. Murphy, L.J., C. Seneviratne, G. Ballejo, F. Croze, and T.G. Kennedy. 1990. Identification and characterization of a rat decidual insulin-like growth factor-binding protein complementary DNA. Mol. Endocrinol. 4:329-336.

29. Lewitt, M.S., H. Saunders, and R.C. Baxter. 1992. Regulation of rat insulin-like growth factor-binding protein-1: the effect of insulin-induced hypoglycemia. Endocrinology. 131:2357-2364.

30. Ooi, G.T., L.Y. Tseng, M.Q. Tran, and M.M. Rechler. 1992. Insulin rapidly decreases insulin-like growth factor-binding protein-1 gene transcription in streptozotocin-diabetic rats. Mol. Endocrinol. 6:2219-2228.

31. Backer, J.M., M.J. Myers, X.J. Sun, D.J. Chin, S.E. Shoelson, M Miralpeix, and M.F. White. 1993. Association of IRS-1 with the insulin receptor and the phosphatidylinositol 3'-kinase. Formation of binary and ternary signaling complexes in intact cells. J. Biol. Chem. 268:8204-8212.

32. Myers, M.J., J.M. Backer, X.J. Sun, S. Shoelson, P. Hu, J. Schlessinger, M. Yoakim, B. Schaffhausen, and M.F. White. 1992. IRS-1 activates phosphatidylinositol 3'-kinase by associating with src homology 2 domains of p85. Proc. Natl. Acad. Sci. USA. 89:10350-10354.

33. White, M.F. 1994. The IRS-1 signaling system. Curr. Opin. Genet. Dev. 4:47-54.

34. Okada, T., Y. Kawano, T. Sakakibara, O. Hazeki, and M. Ui. 1994. Essential role of phosphatidylinositol 3-kinase in insulin-induced glucose transport and antilipolysis in rat adipocytes. Studies with a selective inhibitor wortmannin. J. Biol. Chem. 269:3568-3573.

35. Backer, J., M. Myers, S. Shoelson, D. Chin, X. Sun, M. Miralpeix, P. Hu, B. Margolis, E. Skolnik, J. Schlessinger, and M. White. 1992. The phosphatidylinositol 3'-kinase is activated by association with IRS-1 during insulin stimulation. EMBO (Eur. Mol. Biol. Organ.) J. 11:3469-3479.

36. Sun, X.J., P. Rothenberg, C.R. Kahn, J.M. Backer, E. Araki, P.A. Wilden, D.A. Cahill, B.J. Goldstein, and M.F. White. 1991. Structure of the insulin receptor substrate IRS-1 defines a unique signal transduction protein. $\mathrm{Na}$ ture (Lond.). 352:73-77.

37. Morgan, D., K. Jarnagin, and R. Roth. 1986. Purification and characterization of the receptor for insulin-like growth factor 1. Biochemistry. 25: $5560-5564$

38. Caro, J.F., J. Poulos, O. Ittoop, W.J. Pories, E.G. Flickinger, and M.K. Sinha. 1988. Insulin-like growth factor I binding in hepatocytes from human liver, human hepatoma, and normal, regenerating, and fetal rat liver. J. Clin. Invest. 81:976-981.

39. Pagliassotti, M.J., L.C. Holste, M.C. Moore, D.W. Neal, and A.D. Cherrington. 1996. Comparison of the time courses of insulin and the portal signal on hepatic glucose and glycogen metabolism in the conscious dog. J. Clin. Invest. $97: 81-91$.

40. Hartman, M., P. Clayton, M. Johnson, A. Celniker, A. Perlman, K. Alberti, and M. Thorner. 1993. A low dose euglycemic infusion of recombinant human insulin-like growth factor I rapidly suppresses fasting-enhanced pulsatile growth hormone secretion in humans. J. Clin. Invest. 91:2453-2462.

41. Boulware, S.D., W.V. Tamborlane, N.J. Rennert, N. Gesundheit, and 
R.S. Sherwin. 1994. Comparison of the metabolic effects of recombinant human insulin-like growth factor-I and insulin. Dose-response relationships in healthy young and middle-aged adults. J. Clin. Invest. 93:1131-1139.

42. McAloon-Dyke, M., N. Kukagawa, K. Minaker, H.-P. Guler, R. Wolfe, and D. Elahi. 1994. The effects of insulin-like growth factor-I on leucine and glucose kinetics in type II diabetes. Clin. Res. 42:118A.

43. Hussain, M.A., O. Schmitz, A. Mengel, A. Keller, J.S. Christiansen, J. Zapf, and E.R. Froesch. 1993. Insulin-like growth factor I stimulates lipid oxidation, reduces protein oxidation, and enhances insulin sensitivity in humans. $J$. Clin. Invest. 92:2249-2256.

44. Zenobi, P.D., G.S. Jaeggi, W.F. Riesen, M.E. Roder, and E.R. Froesch. 1992. Insulin-like growth factor-I improves glucose and lipid metabolism in type 2 diabetes mellitus. J. Clin. Invest. 90:2234-2241.

45. Prip-Buus, C., S. Thumelin, F. Chatelain, J.-P. Pegorier, and J. Girard. 1995. Hormonal and nutritional regulation of liver fatty acid oxidation and ketogenesis during development. Biochem. Soc. Trans. 23:500-506.

46. Pegorier, J.P., B.C. Prip, P.H. Duee, and J. Girard. 1992. Hormonal control of fatty acid oxidation during the neonatal period. Diabetes Metab. 18: $156-160$.

47. Girard, J., P. Ferre, J.P. Pegorier, and P.H. Duee. 1992. Adaptations of glucose and fatty acid metabolism during perinatal period and suckling-weaning transition. Physiol. Rev. 72:507-562.

48. Jabri, N., D.S. Schalch, S.L. Schwartz, J.S. Fischer, M.S. Kipnes, B.J. Radnik, N.J. Turman, V.S. Marcsisin, and H.P. Guler. 1994. Adverse effects of recombinant human insulin-like growth factor I in obese insulin-resistant type II diabetic patients. Diabetes. 43:369-374.

49. Dohm, G.L., C.W. Elton, M.S. Raju, N.D. Mooney, R. DiMarchi, W.J. Pories, E.G. Flickinger, S.J. Atkinson, and J.F. Caro. 1990. IGF-I-stimulated glucose transport in human skeletal muscle and IGF-I resistance in obesity and NIDDM. Diabetes. 39:1028-1032.

50. Jacob, R.J., R.S. Sherwin, K. Greenawalt, and G.I. Shulman. 1992. Simultaneous insulinlike growth factor I and insulin resistance in obese Zucker rats. Diabetes. 41:691-697.

51. Backeljauw, P., and M. Davenport. 1993. Therapeutic trial of IGF-1 in a patient with Donohue syndrome. Prog. Annu. Mtg. Endocr. Soc. 1320. Las Vegas, NV. The Endocrine Society. Bethesda, MD.

52. Backeljauw, P.F., C. Alves, M. Eidson, W. Cleveland, L.E. Underwood, and M.L. Davenport. 1994. Effect of intravenous insulin-like growth factor I in two patients with leprechaunism. Pediatr. Res. 36:749-754.

53. Hone, J., M. Skarulis, D. Donaldson, C. Cochran, and R. Eastman. 1993. IGF-1 treatment of severely insulin resistant child with short stature and diabetes mellitus. Prog. Annu. Mtg. Endocr. Soc. 1319. Las Vegas, NV. The Endocrine Society. Bethesda, MD.

54. Hussain, M.A., and E.R. Froesch. 1993. Treatment of type A insulin resistance with insulin-like growth factor-I. Lancet. 341:1536-1537.

55. Kuzuya, H., N. Matsuura, M. Sakamoto, H. Makino, Y. Sakamoto, T. Kadowaki, Y. Suzuki, M. Kobayashi, Y. Akazawa, M. Nomura, et al. 1993. Trial of insulin-like growth factor I therapy for patients with extreme insulin resistance syndromes. Diabetes. 42:696-705.

56. Quin, J.D., B.M. Fisher, K.R. Paterson, A. Inoue, G.H. Beastall, and A.C. MacCuish. 1990. Acute response to recombinant insulin-like growth factor I in a patient with Mendenhall's syndrome. N. Engl. J. Med. 323:1425-1426.

57. Takahashi, Y., H. Kadowaki, K. Momomura, Y. Fukushima, T. Orban, T. Okai, Y. Taketani, Y. Akanuma, Y. Yazaki, and T. Kadowaki. 1997. A homozygous kinase-defective mutation in the insulin receptor gene in a patient with leprechaunism. Diabetologia. 40:412-420. 